\title{
MONOAMINE OXIDASE INHIBITORS ISOLATED FROM FERMENTED BROTHS
}

\author{
Tomio Takeuchi, Keiji Ogawa, Hironobu Iinuma, \\ Hiroyukr Suda, Katsuko Ukita, Toshiharu Nagatsu*, \\ MasaAKI Kato and Hamao Umezawa \\ Institute of Microbial Chemistry, Shinagawa-ku, Tokyo, Japan \\ Osamu Tanabe \\ Central Institute of Takara Shuzo Co., Ltd., Kyoto, Japan
}

(Received for publication December 26, 1972)

Cultured broths were screened by measuring the inhibition of monoamine oxidase. Using serotonin as the substrate, two active agents were isolated from Actinomycetes and shown to be pimprinine and trans-cinnamic acid amide, and a compound isolated from a mushroom was identified to be harman. Using benzylamine as the substrate, an inhibitor was isolated from a Streptomyces and shown to be phenethylamine.

As reported by UMEZAWA ${ }^{11}$ antibiotic research has been extended to the study of enzyme inhibitors produced by microorganisms. In this paper, the results obtained by screening for monoamine-oxidase inhibitors are reported.

A crude monoamine oxidase (E.C. 1.4.3.4) was prepared from rat liver and its inhibition by culture filtrates was tested. In part of the study, $2-{ }^{14} \mathrm{C}$-serotonin was used as the substrate and the radioactivity of the reaction product which was extracted with butyl acetate at acid $\mathrm{pH}$ was determined. In another part, benzylamine was used as the substrate and the reaction product was extracted with cyclohexane and measured by its optical density at $242 \mathrm{~nm}$.

Five hundred strains of Actinomycetes were shake-cultured, and two of them showed inhibition of monoamine oxidase action on serotonin. An active compound from the strain MD211-G4 (the strain number in the Institute of Microbial Chemistry) was extracted with butyl acetate and purified by silica gel chromatography and its identity with pimprinine (5,3'-indolyl-2-methyloxazole, I) was confirmed by elemental analysis, molecular peak of mass spectroscopy, ultraviolet spectrum, infrared spectrum and $\mathrm{nmr}$ analysis. Pimprinine was first isolated by BHATE et $a l .^{2)}$ and chemically synthesized by Joshi et $a l .^{3 \text { ? }}$
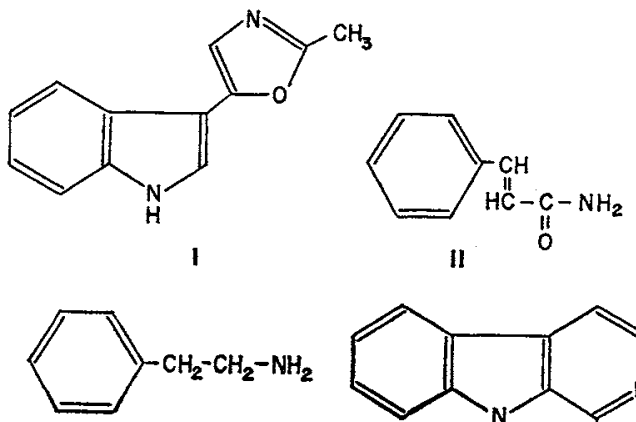

III

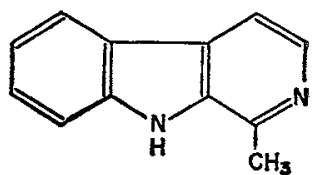

IV

\footnotetext{
* Department of Biochemistry, and Department of Pharmacology, School of Dentistry, Aichi-Gakuin
} University, Nagoya, Japan. 
NARASIMHAN et al.4) reported the protection of mice by pimprinine from convulsions caused by electric shock. Compounds structurally relating to pimprinine, 3substituted indoles, have been studied for monoamine-oxidase inhibition ${ }^{5}$. LINEWEAVER-BURK plots of the results indicate a noncompetitive relation (mixed type) with serotonin as shown in Fig. 1.

An active agent in the culture filtrate of strain MD 235-C2 was extracted with ethyl acetate and purified by silica gel chromatography, and the identity with transcinnamic acid amide (II) was confirmed by elemental analysis, molecular peak in mass spectrum, ultraviolet and infrared spectra and $\mathrm{nmr}$ analysis. Isolation of cinnamic acid amide from Streptomyces was reported by SEKIZAWA ${ }^{6)}$. The tranquilizer effect of derivatives of cinnamic acid has been reported ${ }^{7}$. However, this is the first report that trans-cinnamic acid amide inhibits monoamine oxidase. LINEWEAVER-BURK plots of the results, indicating the noncompetitive relation (mixed type) with serotonin, are shown in Fig. 2.

Testing the activity of culture filtrates of 500 strains of Actinomyces in inhibiting oxidation of benzylamine by monoamine oxidase, a culture filtrate of strain MB 699A 3 was active. The active agent was obtained by carbon adsorption and by carbon chromatography followed by Amberlite CG-50 chromatography. The identity with phenethylamine (III) was confirmed by $\mathrm{nmr}$ and by comparison of its infrared spectum with that of an authentic sample. It is the first isolation of phenethylamine from culture filtrates of Actinomyces. However, the activity of phenethylamine in inhibiting monoamine oxidase has been reported by GoMr et al. ${ }^{8)}$

Mushrooms were shake-cultured in a medium ( $\mathrm{pH} 5.8$ ) consisting of glucose $2.0 \%$,

Fig. 1. Linewhayer-Burk plots of serotonin concentration against rate of oxidative deamination with and without pimprinine.

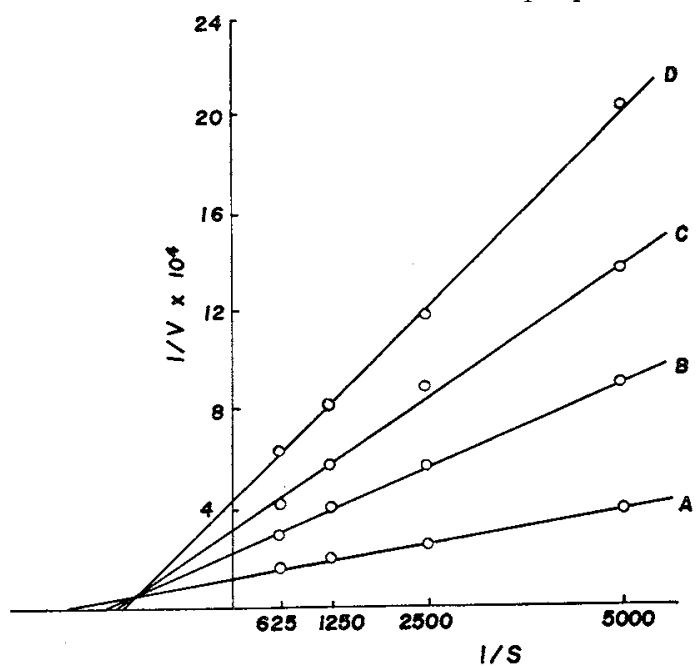

The velocities are expressed as the counts in the product formed.

A : Enzyme alone

B : Enzyme with $2.5 \times 10^{-5} \mathrm{M}$ pimprinine

$\mathrm{C}$ : Enzyme with $5.0 \times 10^{-5} \mathrm{M}$ pimprinine

D : Enzyme with $1.0 \times 10^{-4} \mathrm{M}$ pimprinine

Incubation : 60 minutes.
Fig. 2. Lineweaver-Burk plots of serotonin concentration against rate of oxidative deamination with and without transcinnamic acid amide.

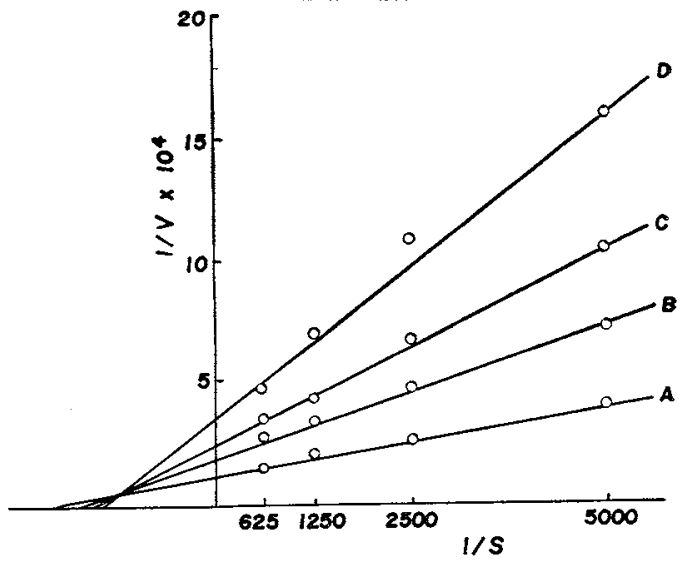

The velocities are expressed as the counts in the Dproduct formed.

A : Enzyme alone

B : Enzyme with $3.40 \times 10^{-4} \mathrm{M}$ t-cinnamic acid amide

$\mathrm{C}$ : Enzyme with $6.80 \times 10^{-4} \mathrm{M} t$-cinnamic acid amide

$\mathrm{D}$ : Enzyme with $1.36 \times 10^{-3} \mathrm{M} t$-cinnamic acid amide

Incubation : 60 minutes. 
peptone $0.5 \%$, yeast extract $0.3 \%, \mathrm{KH}_{2} \mathrm{PO}_{4} 0.3 \%, \mathrm{MgSO}_{4} \cdot 7 \mathrm{H}_{2} \mathrm{O} 0.1 \%$, and the activity of the culture filtrates in inhibiting monoamine oxidase action on serotonin was tested. Filtrate from 4 cultures were active, and the inhibitors were non-dialyzable. However, when 200 cultures were grown in a medium ( $\mathrm{pH} 6.0$ ) consisting of glucose $2.0 \%$, lactose $1.0 \%$, corn steep liquor $6.0 \%$, ammonium nitrate $0.2 \%$ and $\mathrm{CaCO}_{3}$ $0.4 \%, 23$ culture filtrates contained inhibitors. The active agent of Coriolus maximus was extracted with butyl acetate and purified by silica gel chromatography, and the identity with harman (IV) was confirmed by elemental analysis, and infrared and ultraviolet spectra, compared to literature data. The active compounds produced by the other 22 strains were extracted and identity with harman was suggested by thin-layer chromatography using $\mathrm{CHCl}_{3}-\mathrm{MeOH} \quad(10: 1) \quad(\operatorname{Rf} 0.27 \sim 0.28)$ and the ultraviolet spectrum. Thus, production of harman by various mushrooms, Coriolus, Pogonomyces, Lentinus was suggested. Harman was isolated first by PERKin and RoBINOSON $^{9)}$ from plants and later by TAKASE et al. ${ }^{10)}$ from Saké. The monoamine oxidase-inhibiting activity of $\beta$-carbolines structurally related to harman has been studied in detail. $\left.{ }^{5}, 11\right)$ LineweAver-BurK plots of the results indicating the noncompetitive relation are indicated in Fig. 3.

The concentrations of pimprinine, phenethylamine, trans-cinnamic acid amide and harman in the system described in this paper exhibiting $50 \%$ inhibition are shown in Table 1. Pimprinine and harman showed stronger inhibition of serotonin deamination than of benzylamine, and phenethylamine showed stronger effect on benzylamine deamination. Phenethylamine inhibition was noncompetitive (mixed type) with serotonin and competitive with benzylamine.

The results described above indicate that the screening method described is useful in finding and isolating monoamine oxidase inhibitors and depending on different substrates used different active compunds are obtained.

Fig. 3. Lineweaver-Burk plots of serotonin concentration against rate of oxidative deamination with and without harman.

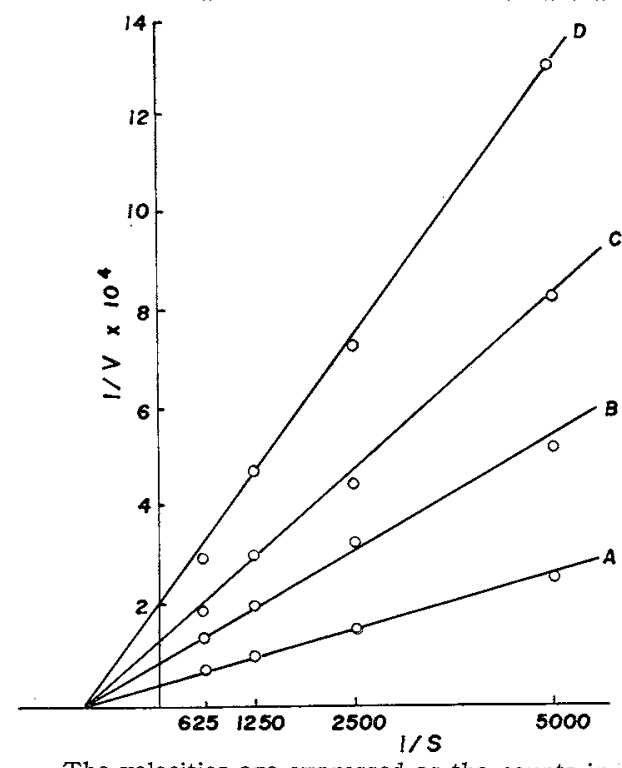

The velocities are expressed as the counts in the product formed.

A : Enzyme alone

B : Enzyme with $1.1 \times 10^{-6} \mathrm{M}$ harman

$C$ : Enzyme with $2.2 \times 10^{-6} \mathrm{M}$ harman

$\mathrm{D}$ : Enzyme with $4.4 \times 10^{-6} \mathrm{M}$ harman Incubation : 60 minutes.

Table 1. $\mathrm{IC}_{50}$ values of inhibitors

\begin{tabular}{l|c|c|c|c}
\hline \multirow{2}{*}{ Substrate } & \multicolumn{3}{|c}{ Inhibitor } \\
\cline { 2 - 5 } & Pimprinine & Phenethylamine & trans-Cinnamic acid amide & Harman \\
\hline Benzylamine & $7.6 \times 10^{-4} \mathrm{M}$ & $3.8 \times 10^{-5} \mathrm{M}$ & $2.3 \times 10^{-4} \mathrm{M}$ & $4.18 \times 10^{-4} \mathrm{M}$ \\
Serotonin & $4.8 \times 10^{-5} \mathrm{M}$ & $6.6 \times 10^{-4} \mathrm{M}$ & $6.4 \times 10^{-4} \mathrm{M}$ & $1.59 \times 10^{-6} \mathrm{M}$ \\
\hline
\end{tabular}




\section{Experimental}

Preparation of crude monoamine oxidase:

Rat liver was homogenized with 6 times volume of $0.25 \mathrm{M}$ sucrose by Teflon homogenizer. The homogenate was centrifuged at $700 \times g$ for 10 minutes and the supernatant at $15,000 \times g$ for 10 minutes. The precipitate was suspended in $0.25 \mathrm{M}$ sucrose and again centrifuged at $15,000 \times g$ for 10 minutes. The precipitate was suspended in $0.25 \mathrm{M}$ sucrose $(4.0 \mathrm{ml} / \mathrm{g}$ of liver) and stored in the frozen state. It was used as the enzyme preparation.

Method of testing the inhibition against monoamine oxidase using serotonin as the substrate:

A reaction mixture consisted of $0.2 \mathrm{ml}$ of the enzyme preparation, $0.14 \mathrm{ml}$ of $1 \mathrm{M}$ phosphate buffer, $\mathrm{pH} 7.4,0.1 \mathrm{ml}$ of $1.6 \times 10^{-2} \mathrm{M}$ serotonin sulfate containing $0.5 \mu \mathrm{Ci} 2^{2-14} \mathrm{C}$ serotonin oxalate, $0.52 \mathrm{ml}$ of water and $0.04 \mathrm{ml}$ of a test material. The substrate was added to start the reaction. After 90 minutes at $37^{\circ} \mathrm{C}$ it was heated at $90^{\circ} \mathrm{C}$ for 3 minutes to cease the reaction. To the reaction mixture $0.15 \mathrm{ml}$ of $1 \mathrm{~N} \mathrm{HCl}$ was added and the mixture was shaken with $3.0 \mathrm{ml}$ of butyl acetate. The butyl acetate was separated by centrifugation and the radioactivity of $1.5 \mathrm{ml}$ was determined by liquid scintilation counter. Percent inhibition was calculated as follows:

$$
\%=[(c-s) /(c-b)] \times 100
$$

where $c$ is the count without test material; $s$ with the test material; $b$ without the test material and the enzyme, but with the heat-denatured $\left(3\right.$ minutes at $\left.90^{\circ} \mathrm{C}\right)$ enzyme.

Method of testing inhibition against monoamine oxidase using benzylamine as the substrate :

The enzyme preparation described above was diluted 24 times with $0.25 \mathrm{M}$ sucrose solution. The reaction mixture was as follows: $0.7 \mathrm{ml}$ of the enzyme solution $(96 \mathrm{ml} / \mathrm{g}$ liver), $0.3 \mathrm{ml}$ of $0.3 \mathrm{M}$ phosphate buffer, $\mathrm{pH} 7.4,0.4 \mathrm{ml}$ of $8.0 \times 10^{-3} \mathrm{M}$ benzylamine, $0.45 \mathrm{ml}$ of water, $0.15 \mathrm{ml}$ of a test material. The reaction was started by addition of the enzyme and continued for 60 minutes at $37^{\circ} \mathrm{C}$. Then $0.15 \mathrm{ml}$ of $60 \%$ perchloric acid was added to stop the reaction. The reaction product was extracted with $2.0 \mathrm{ml}$ of cyclohexane and the optical density of the extract was read at $242 \mathrm{~nm}$. In a test tube, the reaction mixture was incubated without the enzyme and the enzyme was added after the addition of perchloric acid. The value thus obtained was taken as the blank and subtracted from the values obtained from the reaction mixture with the enzyme.

Isolation of pimprinine :

A Streptomyces, strain MD211-C 4, was cultured in a medium ( $\mathrm{pH} 7.4$ ) containing starch $1.0 \%$, glucose $1.0 \%$, meat extract $0.75 \%$, peptone $0.75 \%, \mathrm{NaCl} 0.3 \%, \mathrm{MgSO}_{4} \cdot 7 \mathrm{H}_{2} \mathrm{O}$ $0.1 \%, \mathrm{CuSO}_{4} \cdot 5 \mathrm{H}_{2} \mathrm{O} 7 \mathrm{mg} / \mathrm{liter}, \mathrm{FeSO}_{4} \cdot 7 \mathrm{H}_{2} \mathrm{O} 1 \mathrm{mg} /$ liter, $\mathrm{MnCl}_{2} \cdot 4 \mathrm{H}_{2} \mathrm{O} 8 \mathrm{mg} /$ liter, $\mathrm{ZnSO}_{4}$. $7 \mathrm{H}_{2} \mathrm{O} 2 \mathrm{mg} / \mathrm{liter}$. After $400 \mathrm{ml}$ of the shake-cultured broth was inoculated, the fermentation in 15-liter medium was carried out in a jar fermenter under aeration of 15 liters/ minute and $250 \mathrm{rpm}$ stirring at $28^{\circ} \mathrm{C}$ for 3 days. The culture filtrate was extracted with butyl acetate ( 15 liters), and the extract was washed with water and concentrated to a brown syrup. The active agent was purified by silica gel chromatography with benzeneacetone (100:5 in volume). The active agent was crystallized by evaporation of the active fraction and recrystallized from benzene-ethyl acetate (10:1 in volume). From 28.4 liters of the culture filtrate $58.3 \mathrm{mg}$ of the crystals were obtained. The properties were as follows: m.p. $202^{\circ} \mathrm{C}, \mathrm{UV}_{\lambda_{\max }}^{\mathrm{MeOH}} 224 \mathrm{~nm}(\log \varepsilon 4.36), 266 \mathrm{~nm}(\log \varepsilon 4.13)$, calcd. for $\mathrm{C}_{12} \mathrm{H}_{10} \mathrm{~N}_{2} \mathrm{O}$ : C 72.71, H 5.09, N 14.13, O 8.07; found: C 72.10, H 5.09, N 13.98, O 8.07; $\mathrm{M}^{+}$by mass spectroscopy 198. These data and the infrared spectrum were identical with those of pimprinine.

Isolation of trans-cinnamic acid amide:

A Streptomyces, strain $\mathrm{MD} 235-\mathrm{C} 2$, was cultured in a medium ( $\mathrm{pH} 6.0$ ) consisting of soybean meal $2.5 \%$, soybean oil $2.0 \%$, potato starch $0.5 \%$, glucose $0.5 \%$, yeast extract 
$0.2 \%$. After $400 \mathrm{ml}$ of the shake-cultured broth was inoculated, the fermentation in 15 liters medium was carried out in a jar fermenter at $28^{\circ} \mathrm{C}$ for 4 days under aeration of 15 liters/minute and stirring at $250 \mathrm{rpm}$. The active agent showing inhibition in the reaction mixture containing serotonin was extracted with ethyl acetate, the same volume as the filtrate. The ethyl acetate was washed with water and concentrated to a syrup $(30 \mathrm{~g})$. The syrup was subjected to silica gel chromatography using chloroform-methanol (100:2 in volume). Concentration of the active fraction gave crystals of the active agent. The mother liquor was subjected to silica gel chromatography using benzene - ethyl acetate $(1: 1)$ and the evaporation of the active fraction gave also crystals of the active agent. The crystals were combined and recrystallized from ethyl acetate. From 13 liters of a culture filtrate $1.79 \mathrm{~g}$ crystals was obtained. The properties were as follows: m.p. $145^{\circ} \mathrm{C}$, $\mathrm{UV}_{\lambda_{\max }}^{\mathrm{MeOH}}$ $216 \mathrm{~nm}(\log \varepsilon 4.32), 273 \mathrm{~nm}(\log \varepsilon 4.30)$; calcd. for $\mathrm{C}_{9} \mathrm{H}_{9} \mathrm{NO}: \mathrm{C} 73.45, \mathrm{H} \mathrm{6.16, \textrm {N }} 9.52$, O 10.87; found $\mathrm{C} 71.77, \mathrm{H} 5.94, \mathrm{~N} 9.55, \mathrm{O} 10.29 ; \mathrm{M}^{+}$by mass spectroscopy 147 . The identity with trans-cinnamic acid amide was confirmed by comparison of the infrared and nmr spectra with those of an authentic sample.

Isolation of phenethylamine:

A Streptomyces, strain MB 699-A 3, was cultured in the following medium ( $\mathrm{pH}$ 7.0): glycerol $3.0 \%$, NZ-amine $2.0 \%$, yeast extract $0.2 \%, \mathrm{NaCl} 0.3 \%$. After $400 \mathrm{ml}$ of a shake-cultured broth was inoculated, the formentation in 15 liters medium was continued for 3 days at $28^{\circ} \mathrm{C}$ under aeration of 15 liters $/$ minute, and $250 \mathrm{rpm}$. The active agent was adsorbed on carbon (2.0\% of the filtrate), and eluted with $50 \%$ acetone (5 liters, 3 times) at $\mathrm{pH}$ 2.0. After concentration and drying, a brown powder $(51.0 \mathrm{~g})$ was obtained. A $40 \mathrm{~g}$ portion was subjected to carbon column chromatography with $80 \%$ methanol followed by Amberlite CG-50 $\left(\mathrm{NH}_{4}{ }^{+}\right)$chromatography using $0.1 \mathrm{~N} \mathrm{NH} \mathrm{NH}_{4} \mathrm{OH}$ for elution. The evaporation of the active fraction under reduced pressure gave a crystalline active compound which showed one spot of $\mathrm{Rm} 1.3$ (taking L-alanine as 1.0) in high voltage electrophoresis under $3,000 \mathrm{~V}$. The identity with phenethylamine was suggested by $\mathrm{nmr}$ spectrum and finally confirmed by comparion of the infrared spectrum with that of an authentic sample.

Isolation of harman:

A strain of Coriolus maximus was cultured in the following medium (pH 6.0): glucose $2.0 \%$, lactose $1.0 \%$, corn steep liquor $6.0 \%, \mathrm{NH}_{4} \mathrm{NO}_{3} 0.2 \%, \mathrm{CaCO}_{3} 0.4 \%$. After 4 days shake-cultured broth was inoculated, the fermentation in 15 liters medium was carried out under aeration of 15 liters/minute and stirring at $250 \mathrm{rpm}$ at $28^{\circ} \mathrm{C}$ for 47 hours. The culture filtrate (12 liters) was extracted with the same volume of butyl acetate at $\mathrm{pH} 8.0$, and after concentration to 4.3 liters under reduced pressure, the active agent inhibiting monoamine oxidase was transferred into 4 liters of water at $\mathrm{pH} 2.0$. The active agent was transferred again into 4.3 liters of butyl acetate at $\mathrm{pH} 8.0$, and then evaporated under reduced pressure to give a white powder $(545 \mathrm{mg})$. The active agent was purified by silica gel column chromatography using chloroform - methanol $(100: 1)$, and the evaporation of the active fraction gave crystals $(86.1 \mathrm{mg})$ which were recrystallized from chloroform: m.p. $230 \sim 232^{\circ} \mathrm{C}, \mathrm{UV}_{\lambda_{\max }^{\mathrm{MeOH}}}^{\mathrm{MeOH}} 235 \mathrm{~nm}(\log \varepsilon 4.74), 241 \mathrm{~nm}(\log \varepsilon 4.69), 251 \mathrm{~nm}(\log \varepsilon 4.51)$, $283 \mathrm{~nm}$ (shoulder), $289 \mathrm{~nm}$ ( $\log \varepsilon 4.37), 337 \mathrm{~nm}(\log \varepsilon 3.8), 351 \mathrm{~nm}(\log \varepsilon 3.8) ;$ UV $\mathrm{MeOH}_{\operatorname{mxa}} \mathrm{HCl}$ $249 \mathrm{~nm}(\log \varepsilon 4.62), 302 \mathrm{~nm}(\log \varepsilon 4.35)$. Reviewing monoamine oxidase inhibitors, a close structural relationship with harman, 1 -methyl- $\beta$-carboline, was suggested. The result of the elemental analysis was as follows: calcd. for $\mathrm{C}_{12} \mathrm{H}_{10} \mathrm{~N}_{2}$ : C 79.09, $\mathrm{H} \mathrm{5.53, \textrm {N }} 15.38$;

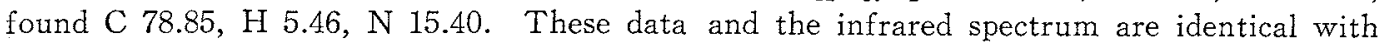
those described for harman, and identity was also supported by the nmr spectrum.

\section{References}

1) Umezawa, H.: Enzyme Inhibitors of Microbial Origin. University of Tokyo Press, 1972

2) Bhate, D. S.; R. K. HulyalkaR \& S. K. Menon: Isolation of iso-butyropyrrothine along with thiolutin and aureothricin from a Streptomyces, sp. Experientia $16: 504 \sim 505,1960$ 
3) Joshr, B. S. \& W. I. TAYLOR : The structure and synthesis of pimprinine. Tetrahedron 19: 1437 1439, 1963

4) Narasimhan, M. J. \& V. G. Ganla : Pimprinine in the treatment of hyperkinetic diseases. Hindustan Antibiot. Bull. $9: 138 \sim 141,1967$

5) Ho, B. T.: Monoamine oxidase inhibitors. J. Pharm. Sciences $61: 821 \sim 837,1972$

6) Sekizawa, Y.: trans-Cinnamic acid amide as a metabolic product of Streptomyces. J. Bact. $45: 9 \sim 11,1958$

7) American Cyanamid Company: Preparation of 3,4,5-triloweralkoxy-cinnamide. Japanese Patent 37-10781, 1962

8) Gomr, Y.: Studies on monoamine oxidase inhibitors. IV. On the mode of nonspecific inhibitory action. Yakugaku Zasshi $86: 483 \sim 487,1966$

9) Perkin, W. H. \& R. Robinson: Harmine and hammalin. J. Chem. Soc. 115 : 967 971, 1919

10) Takase, S. \& H. Murakamr : Studies on the fluorescens of Saké. I. Fluorescens spectrum of saké and identification of harman. Agr. Biol. Chem. $30: 869 \sim 876,1966$

11) Ho, B. T.; K. Li, K. E. Walker, L. Woyne Tansey, P. M. Kralitk \& W. M. MoIsaac : Inhibitors of monoamine oxidase. VI. Effects of substitution on inhibitory activity of 6 (or 8 ) substituted $\beta$-carbolines. J. Pharm. Sci. $59: 1445 \sim 1448,1970$ 